\title{
Clients reviews on the web : toward a new knowledge of touristic space. Case of Djerba in
} Tunisia

Avis des clients sur le web : vers une nouvelle connaissance de l'espace touristique. cas de Djerba en Tunisie

Los comentarios de los clientes en la red : hacia un nuevo conocimiento del espacio turístico. caso de dDerba en Túnez

\section{Bassem Neifar}

\section{OpenEdition}

\section{Journals}

Electronic version

URL: http://journals.openedition.org/ctd/944

DOI: $10.4000 /$ ctd. 944

ISSN: 2491-1437

\section{Publisher}

Chaire Unesco Pratiques émergentes en technologies et communication pour le développement

Printed version

Date of publication: 30 October 2016

ISBN: 2491-1437

\section{Electronic reference}

Bassem Neifar, «Clients reviews on the web : toward a new knowledge of touristic space. Case of Djerba in Tunisia », Communication, technologies et développement [Online], 3 | 2016, Online since 30 October 2016, connection on 13 June 2020. URL : http://journals.openedition.org/ctd/944 ; DOI : https://doi.org/10.4000/ctd.944

\section{This text was automatically generated on 13 June 2020 .}

Communication, technologies et développement 


\title{
Clients reviews on the web : toward a new knowledge of touristic space. Case of Djerba in Tunisia
}

\author{
Avis des clients sur le web : vers une nouvelle connaissance de l'espace \\ touristique. cas de Djerba en Tunisie \\ Los comentarios de los clientes en la red : hacia un nuevo conocimiento del \\ espacio turístico. caso de dDerba en Túnez
}

Bassem Neifar

\section{Tourism in Djerba between official documents and travel guides}

\section{The main assets of tourism in Djerba}

The local context

Djerba is an hour-and-a-half by car from Tripoli and seven hours from Tunis (the capital). It is three hours by air from European countries, from which many tourists arrive. The island is close to the mainland on two sides : First, in the West, between the Jorf and Ajim and second, in the East, between Zarzis and El Kantara. Ajim and the Jorf are separated by a strait of $2 \mathrm{~km}$, which is crossed by ferries. On the Zarzis side, the island is connected to the mainland by a $7.5 \mathrm{~km}$ bridge (fig. 1, fig. 2). Djerba is considered a peninsula rather than an island; but, most tourists arrive by air via the Djerba-Zarzis international airport. The population of the island was 139,600 in 2004 and 163,726 in 2014 ; the island has an area of over $514 \mathrm{~km}^{2}$. The island is formed by three administrative delegations related to the governorate of Medenine; these three cities have different functions. Houmt Souk is the capital of the island and the centre of local administrations; Midoun is the nearest centre of tourism activities; Ajim is further away from the local issues despite of its important location in front of Jorf through which all ferry passengers must pass. 
Figure1. Location of Djerba island in Tunisia (source : nationsonline.org)

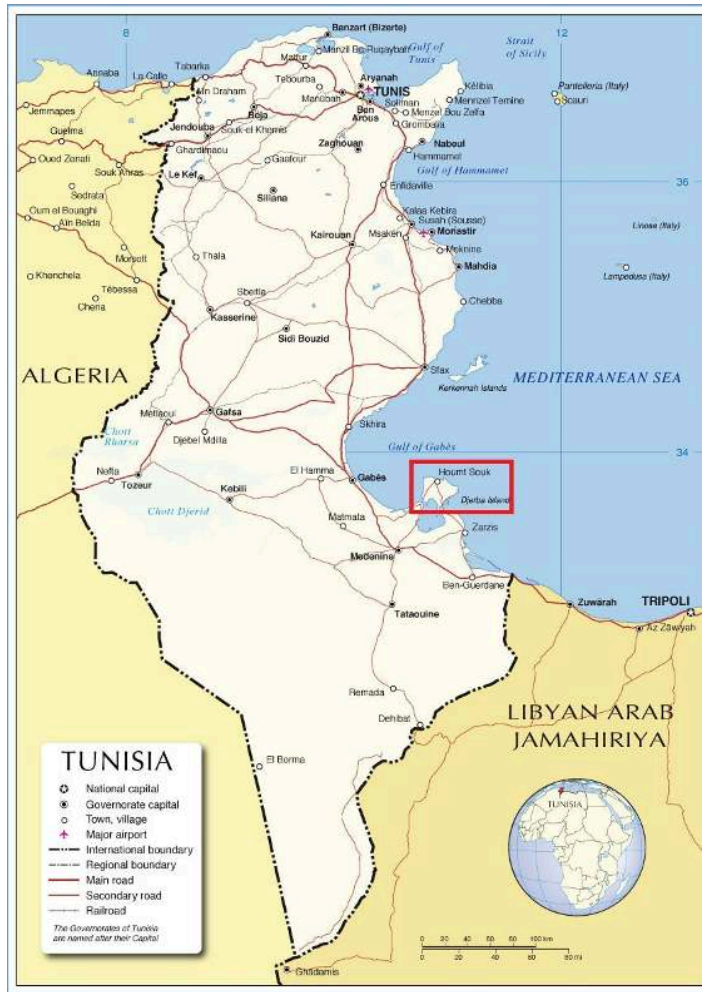

Figure 2 Map of Djerba (source : Google map)

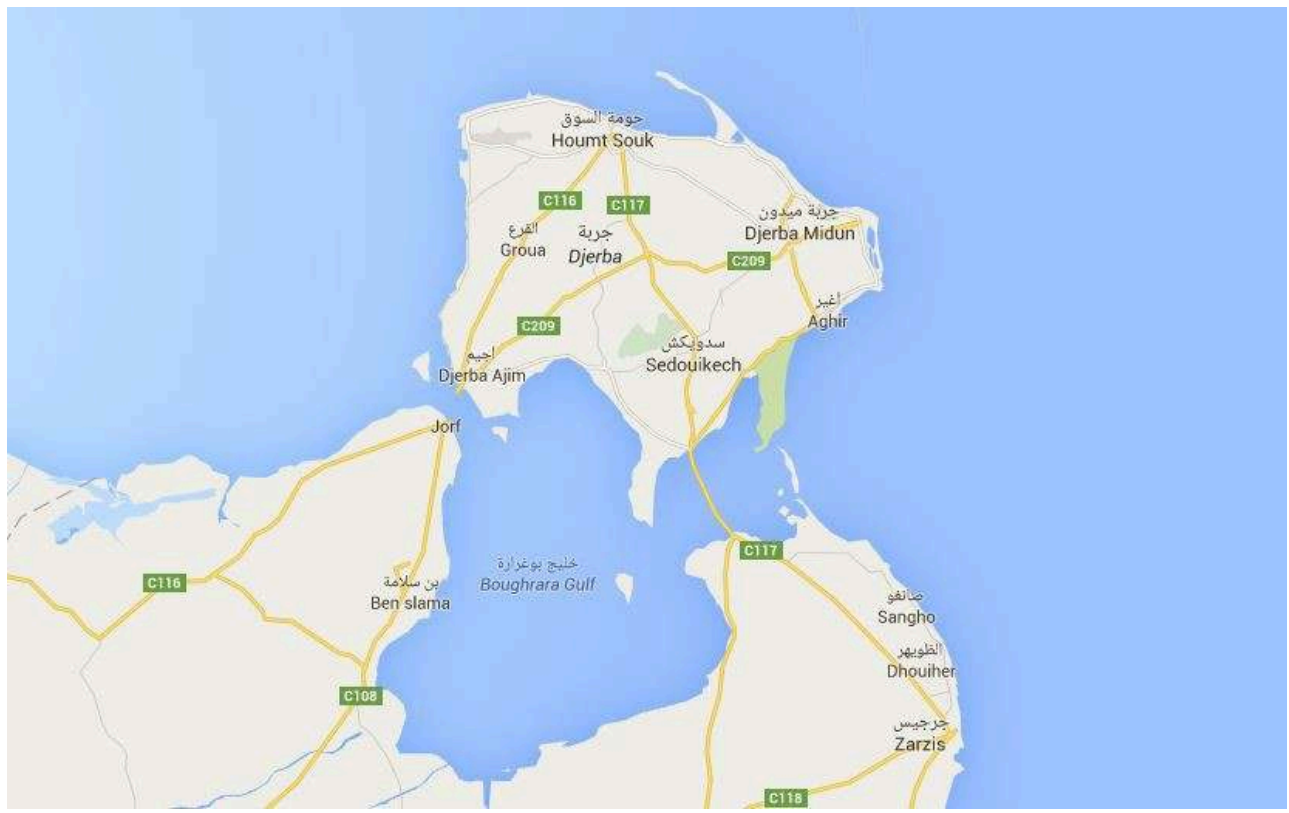

The climate of Djerba is one of its assets. Tourists enjoy the sunshine and the softness of the island temperatures; these are moderate in winter and lower than the rest of Tunisia in the summer. By comparing and measuring temperatures on the site accuWeather.com (between January 15 and February 15, 2016), we found temperatures are more stable and temperate than in Marrakech. The mean temperatures range from $12^{\circ}$ to $25^{\circ}$; in Marrakech mean temperatures vary from $6^{\circ}$ to $26^{\circ}$. In Djerba sandy 
beaches extend over twenty kilometres from the southeast to the northeast of the island.

The national context

In Tunisia, tourism was not a state policy priority until the first half of the 1960s (Neifar, 2011). Tourism played a minor role in political programs. The success of tourism in 1964 prompted the government to change its strategy and place more importance on this sector. In 1965, a tourism planning programme emerged. The state disengaged more and more from direct investments in tourism while encouraging private and foreign investors to invest in this sector. The 66-339 decree of 2 September 1966 gave investors significant tourism facilities. This sector was a refuge sector at that time, as compared to the severe state control of other economic branches. The main areas of tourism investment were Hammamet, Nabeul, Sousse, Monastir, and DjerbaZarzis.

Djerba tourism began in 1954 when the founder of Club Med, Gilbert Trigano, bought some land on which he built a village with palm huts. The tourist area in Djerba extends over $20 \mathrm{~km}$ from Aghir in the south to Houmt Souk in the north. The number of hotels in Djerba is 89 (30 in Houmt Souk and 59 in Midoun); they are classified from one to five stars. The hotel capacity increased from 8,300 beds in 1975 to 39,000 beds in 2002 and 42,748 beds in $2012^{1}$. The number of tourists in Djerba in 2012 was $906,813^{2}$; the number of overnight stays was $6,392,117$. Djerba tourism is very important to the Tunisian economy, especially because of its job opportunities and an influx of foreign currencies (photo 1).

Photo 1 A daily dynamic landscape in Djerba (by the author, May 2014)

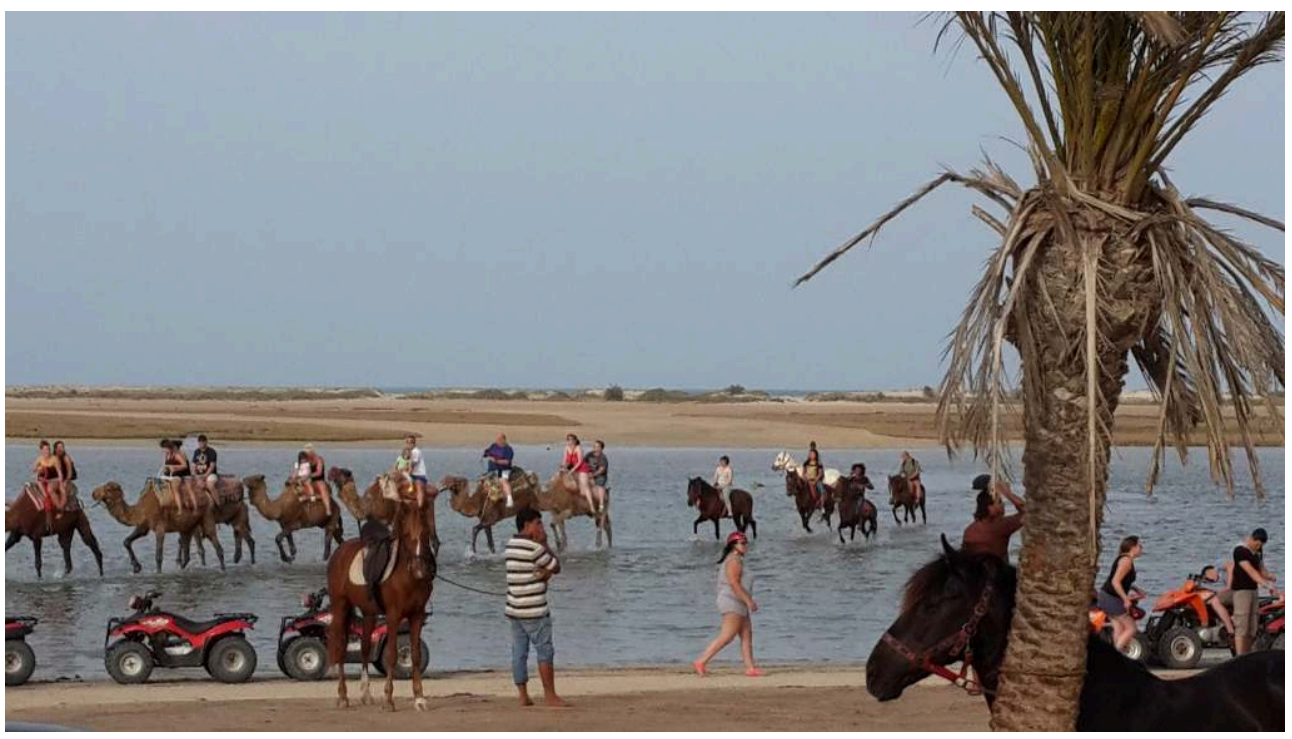

\section{Official guides}

For many years, the Tunisian National Tourist Office (ONTT) has published and distributed various freedocuments(inmanylanguages) thatpromotetourisminthecountry. Thesedocuments advertise both specific destinations and the country as a whole. For Djerba, the ONTT published a 16 pages document that focuses on the following points : 
The location of the island in the Mediterranean Sea,

Its mild climate,

The history of the island (since antiquity) and a description of monuments and vestiges,

Handicrafts and local know-how,

Hotels and inspiring architecture,

Relaxation and leisure activities,

Other areas of South Tunisia accessible from Djerba.

These documents, although interesting, come from the touristic department; they show the official views of the state. They do not reflect the opinions of tourists who desire authentic experiences of Djerba. In addition to official documents, a large number of travel guides allow tourists to travel anywhere.

\section{The travel guides}

For decades, firms in tourists' countries-of-origin have published many travel guides to help tourists in the countries they visit. These travel guides provide information on Djerba history and geography; they give overviews of the political system, infrastructure, national currency, and what to do and avoid as a tourist. Several travel guides exist on the market : Lonely Planet, The Rough Guide, Michelin, Routard, Petit Futé, etc. For this work, we have listed a number of guides that have complete volumes dedicated to Tunisia with parts that focus on the island of Djerba. This is the case with the French guides « Routard Guide, Tunisia, 2016 -2017 » and « Géoguide Tunisia ». The "Petit futé » also offers a complete volume for Tunisia; however, it is also the only guide in which competitors have presented a special volume on Djerba. We'll start by using the example of the " 2016 Géoguide » and « Routard Guide, Tunisia, 2016 -2017 », before focusing on « Petit futé », which is completely dedicated to Djerba.

Géoguide and Routard Guide

Géoguide was born through a marriage between the Gallimard and Geo magazine. On the contrary, the Routard guide was published by Hachette and launched in 1973. Pages 313-346 of the Routard Guide are dedicated to Djerba (33 pages). In contrast, pages 330-352 of Géoguide Tunisia are dedicated to Djerba (22 pages). In both guides, the pages dedicated to Djerba highlight generalisations of Djerba, such as religion, culture, history, tourist areas, and cultural attractions on the coast and inside the island. The last pages of the guides mainly present discussions of recommended places for accommodation, catering, etc.

\section{Le Petit Futé Guide}

17 We chose to examine on Le Petit Futé with a special volume on Djerba. This French travel guide has existed since 1976. The 2013 Le Petit Futé guidebook is a 96 pages document with a summary; it covers the following topics :

Discovery (10 keywords about Djerba, Djerba Overview, History, and Tunisian cuisine).

What to see and do

Restaurants and nightlife

Getaways in the region

How to organize your stay. 

during their stays in Djerba and Tunisia. Nevertheless, it is still a personal vision of professional travel; it cannot show the hidden face of tourism and the authenticity of the place increasingly sought by tourists. "The potential tourist is no longer dependent on official information from professionals or tourist guides" (Viallon P., 2013, p. 9). Tourists use more and more new technologies (especially the Internet) to prepare their trips. They carefully read guest reviews and Internet user rankings of hotels and restaurants - as well as full details about the cities and countries they visit. The field of Web 2.0 allows the "man on the street" to review and publish content to be broadcast to thousands of Internet users.

\section{Internet and touristic spaces}

\section{The new role of Internet in the knowledge of touristic spaces}

Our transition from paper to digital communication has transformed the relationship of people to those touristic spaces. Indeed, this involvement is more important; simple users become players in the creation of knowledge related to these spaces.

From the Web to the Web 2.0

The diffusion of Web content has been exclusively reserved for developers and technical web experts. At the same time, the websites are portals for companies and private or public organizations. This situation has changed over recent years. New web applications allow users to publish and distribute their content on the web without being connoisseurs or technicians. This domain, Web 2.0, was launched for the first time in 2004.

Web 2.0 and the synchronization of collective intelligence

With the development of Web 2.0, sharing experiences, ideas and advice on the web (and on social networks) has led to a maturity that is characterized by a collective intelligence. Boris Beaude (2012), a French geographer said : "The ability of individuals to be informed, to coordinate and to cooperate is so increased as the economy, culture and politics are transformed by the spread of collective intelligence to all individual practices...". (p. 162)

The crowdsourcing

Crowdsourcing is a neologism that refers to mass participation in the development of a project. "Crowdsourcing, crowdfunding, collective intelligence or wisdom of crowds are opportunities for humanity to find the space of its collective expression". (Beaude, 2012, p. 149). Crowdsourcing can be active, as when people connect and work together to find a solution to a problem; it is passive when they interpret results to understand phenomena. Many sites rely on crowdsourcing, including WikiLeaks, Wikipedia, Openstreetmap, and TripAdvisor. For this study, we chose to study client comments on the Tripadvisor website.

\section{Tripadvisor : a mine of information dedicated to travellers and tourist Establishments}

Tripadvisor is an American website that advises travellers; it was created in 2000. Tripadvisor claims 250 million reviews and opinions on 5.2 million accommodations, restaurants and attractions. This "giant of tourism" is present in 45 countries. It manages and operates websites under 23 brands in the travel industry ${ }^{3}$. The 
Tripadvisor's TripBarometer ${ }^{4}$ survey is conducted annually by Tripadvisor ; in 2014 , the survey covered 50,637 internet users. This survey showed that $65 \%$ of respondents are influenced by comments and reviews on the Internet when choosing destinations. TripAdvisor inspires $74 \%$ of travellers and influences $78 \%$ in choosing a destination. This site is based on opinions and customer feedback (fig. 3). TripAdvisor is a dynamic source of information and updates for hotels, vacation rentals, flights, and tourist attractions ; it also features a discussion forum.

Djerba, like other touristic islands and spaces, is well-referenced on the Tripadvisor portal; it lists 110 hotels $^{5}$ and shows 35,000 comments and 1308 reviews of the 38 attractions on the island. Travellers use this website to prepare their trips to Djerba and make reservations. We also noted the presence of a forum started in March 2007 that discussed Djerba (among other things) with 474 threads. We will focus on hotel reviews and forum posts.

Figure 3. Review from English tourist giving advices to other tourists (source : TripAdvisor)

The Discussion forum on Tripadvisor

On the Tripadvisor forum we mentioned in the last section, we identified 474 threads dedicated to Djerba. We classified discussions about 10 key themes: about hotels, general information, weather, safety after the Arab Spring, scams and misadventures, ads for travellers to Djerba, spas and thalasso in Djerba, and others) (fig. 4). The majority of these discussions (57\%) concerned hotel choice in Djerba; $21 \%$ of discussions were related to the need for information about Djerba.

Figure 4. Graph of principal topics found in the forum of Tripadvisor

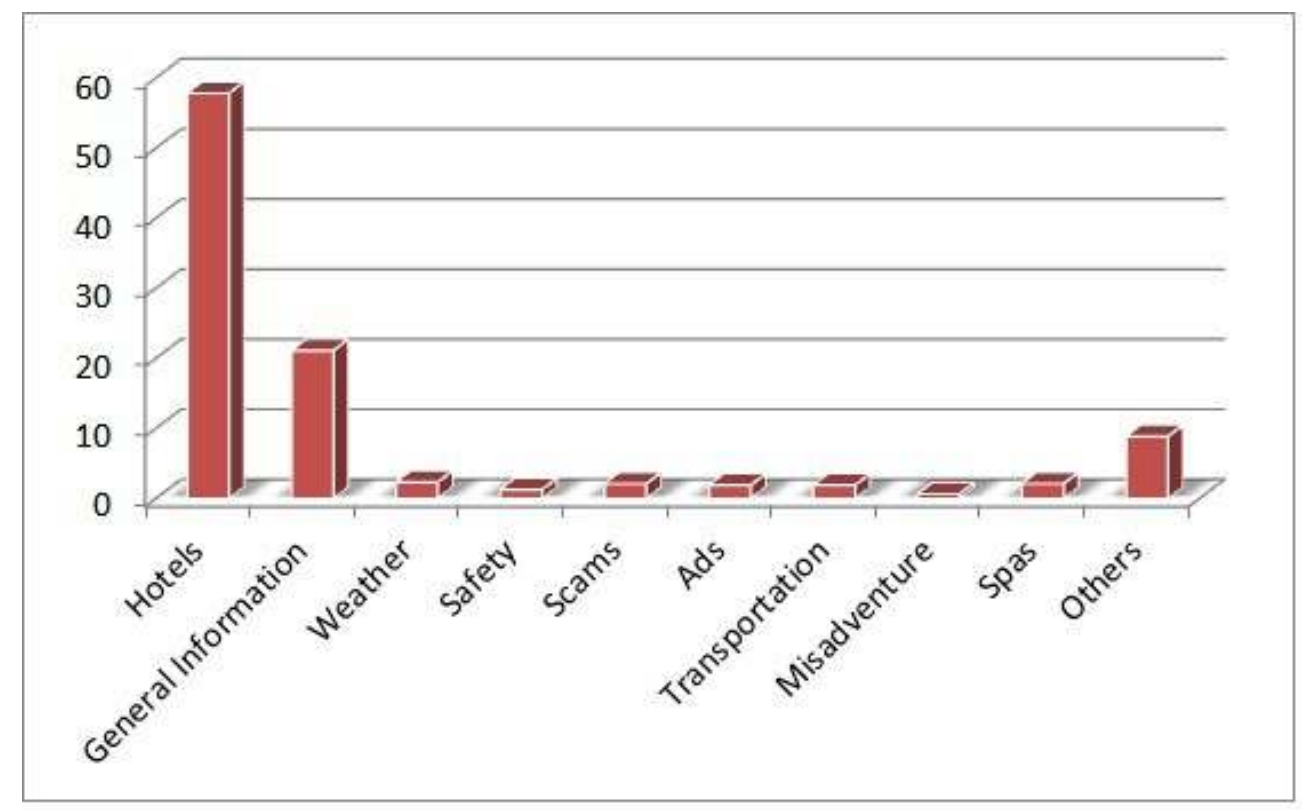

Discussion forums are important for customers preparing to travel to Djerba. We found information on the progress of their stays and with a return on the customer experience after their stays (and especially their thoughts about hotels). Discussions on the forum are not as important as customer reviews on the site. Despite of this, it is still a good source of information about staying in Djerba. Customer reviews on Tripadvisor, 
in which they describe hotels and activities after their stays, are of greatest important interest to Internet users.

Customer reviews on Tripadvisor

\section{reviews are given emotionally or speak against certain hotel employees and managers. We know some comments may come also from competitors. \\ Before treating and analysing reviews, we showed, we were aware that some customer}

Figure 5. Graph of the number of reviews related to the sample used for this study

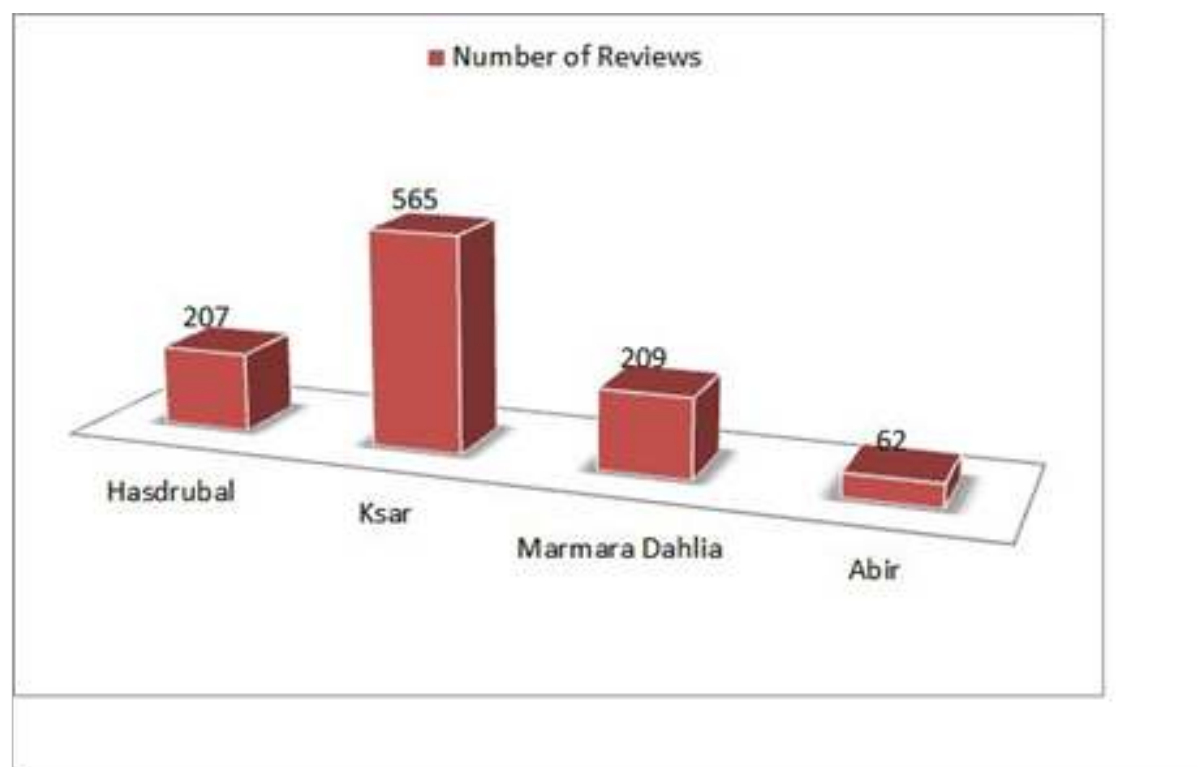

For this study, we sampled 4 hotels : Hasdrubal Thalassa \& Spa Djerba (five stars), Ksar Djerba, Club Marmara Dahlia and Abir (three stars). By August 2014, these hotels received 1,043 reviews and had different rankings on Tripadvisor (fig. 5).

Hasdrubal Thalassa \& Spa Djerba were ranked third out of 112 Djerba hotels on 08.10.2014 with 207 reviews; it regressed to the sixth rank with 316 reviews on 01.31.2016. Ksar Djerba was ranked 40th out of 112 Djerba hotels on 08.10.2014; it received 565 reviews and regressed to the 46th rank with 746 reviews on 01.31.2016. Club Marmara Dahlia was ranked 58 out of 112 Djerba hotels on 08.10.2014; it had 202 reviews and progressed to 40th of 110 Djerba hotels and 541 reviews on 01.31.2016. Abir was ranked 98th of 112 hotels in Djerba on 10.10.2014; it got 61 reviews and regressed to the 101st rank with 62 reviews on 01.31.2016. emphasised that most of the clients are French-speaking or French. This explains the large number of French reviews for Djerba. This is not the same for the region of Sousse, Monastir, and Hammamet, where, besides French customers, the other major demographics were Anglophone and Algerian customers. Mainly due to geographical proximity, Djerba is also a popular destination for Libyan customers. However, the Libyan customers do not usually leave Internet reviews after their stay.

In the tables below (tables 1, 2), we have provided a list of the various topics covered in the reviews. These reviews can be positive and negative. Through the reviews, we established a list of positive comments and a list of negative comments. A comment is seen as being negative if negative adjectives are used in the title or in the comment. For 
example, words and phrases such as « horrible ", " unadvisable ", and « scam to avoid » indicate negativity. The review also qualifies as being negative when the hotel is rated between 0 and 3 . In the case of positive reviews, the adjectives used in the title and comments are positive. For example, words and phrases such as "great stay ", "I will return", and " wonderful stay » indicate positivity. The rating of the hotel may also indicate a positive review.

Table1. List of topics related to negative reviews

\begin{tabular}{|c|c|}
\hline \multicolumn{2}{|l|}{ Negative Reviews } \\
\hline Topics & Details \\
\hline Restoration & $\begin{array}{l}\text { (Food is not varied, lack of taste, lack of freshness of products, problems } \\
\text { with the all-inclusive...). }\end{array}$ \\
\hline Hygiene and cleanliness & (Public areas, swimming pools, beaches, rooms, etc.) \\
\hline Staff behaviour & $\begin{array}{l}\text { (Lack of interest, lack of professionalism, lack of seriousness, acts of } \\
\text { harassment against of women). }\end{array}$ \\
\hline $\begin{array}{ll}\text { Misadventures } & \text { and } \\
\text { disappointments } & \end{array}$ & (Tour operator trips, scams, etc.) \\
\hline
\end{tabular}

Table 2. List of topics related to positive reviews

\begin{tabular}{|c|c|}
\hline \multicolumn{2}{|l|}{ Positive Reviews } \\
\hline Topics & Details \\
\hline The overall experience & Destination, equipment comfort, weather. \\
\hline Staff & Human and professional qualities of staff. \\
\hline Hygiene and cleanliness. & Hotel rooms, hallways and the lobby. \\
\hline Food & The quality and the Variety of food. \\
\hline A response to a customer & Answers to negative customer reviews. \\
\hline
\end{tabular}

37 By observing these reviews, we noted the number of negative comments increases during the two months that characterize the peak tourist season : July and August. In June and September, reviews were rather positive. In June, staff was motivated and less tired than in other periods. Some had just begun seasonal work for the summer. June is also the beginning of the summer season for permanent employees. In September, a decline in tourist numbers allows hoteliers to take a breath and correct any mistakes that happened during July and August. These factors explain the majority of the positive reviews for these two months. Nevertheless, in July and August, the context is quite different. Customers are much more demanding during the peak tourist season. 
This is a period of annual vacations in many countries. In general, the quality of service declined in hotels during the peak tourist season. Some employees were seasonal and intruders to touristic sector. In many cases, students or emigrants from the Djerba hinterland are not qualified though they come to the island looking for work. This partly explains customers' negative comments during the peak season.

\section{Towards a new understanding of tourism in Djerba island}

\section{A transparent and subjective space}

Through customer hotel reviews and forum discussions on Tripadvisor, the tourist space has more traceability than ever. Customers have more information than before as they choose destinations, hotel, attractions, sights etc. This tourist space, as described by customers, is not regulated; it imposes its own vision and has its own benchmarks. Marketing to tourists no longer involves images on postcards and descriptions in official documents and travel guides. "How to think this transposition of credibility or the legitimacy of experts, to amateurs tourists? " (Viallon P., 2013, p. 9). Travellers are typically sincere and emotional, though sometimes unfair in their descriptions of particular barmen, waiters or maids. They do not hesitate mentioning names of people and describe places with great accuracy; they talk about what pleased them and what did not. They augment their reviews with photos of their rooms, bathrooms, corridors, beaches, hotel facades, etc. Client are very demanding when the decor of rooms and hotel do not match the architecture of Djerba. They do not hesitate to criticize or congratulate the security of tourist (fig.6).

Figure 6 A review to encourage tourists to go to Tunisia after the tragic attacks of 2015 (Tripadvisor)
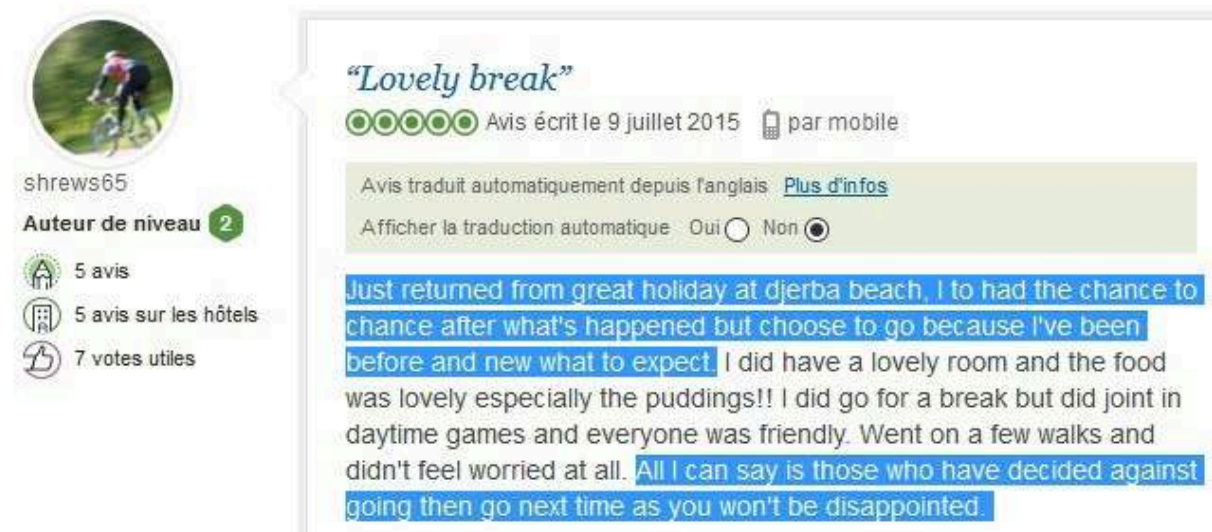

\section{A reading that escapes to geographers?}

The tourist space exists more than ever in the local news and dynamics of local places. It is also sensitive to local social movements and strikes (fig. 7, 8).

The Djerba garbage strike

The Djerba garbage strike in July and August 2014 had negative effects on travellers' reviews: "Right out of the airport, we were shocked by all these piles of garbage 
everywhere on the island, an impression of open dump some trash burning in the streets... The person who welcomed us at the airport justified it by a strike of garbage collection" - Laurent B., Lyon France, August 2014. Another tourist said : "Regarding garbage on the island there is a big worry about the dump that is supposed to collect the garbage from the island, where the filth everywhere, burned at roadsides."

- iphigenie76, Rouen, France August 2014.

Figures 7 \& 8. Examples of reviews from French tourists about pollution and environment in Djerba (Tripadvisor)

Customers do not hesitate to list their requirements, sometimes without taking into account cultural and religious contexts. They also do not hesitate to report workrelated dysfunctions and staff absences (fig. 9). "During Ramadan, at sunset, they close the bar and go all eat at the same time... no substitution, customers wait..." Laurent B., Lyon France, August 2014.

Figure 9. Review from French tourist related to staff behaviour

Which customers in Djerba after terrorist attacks?

There has been an increasing number of local tourists, which can be attributed to the opening of tourism, after the tragic events, to the national customers. However, the question lies in whether the requirements of national customers are similar to those of tourists from Northern and developed countries. Having taken several samples from hotels (Hasdrubal, Ksar Djerba, Abir and Club Marmara Dahlia), we have listed the following remarks :

For Hasdrubal, the first sample of 59 reviews was taken from October 2006 to January 2012. The second sample of 49 reviews was taken from 26 June 2015 to April 27, 2016 just after the terrorist attack in Sousse.

For Ksar Djerba, the first sample of 125 reviews was taken from August to April 2013. A second sample of 94 reviews was taken just after the attack in Sousse.

For the hotel club Marmara Dahlia, the first sample taken with 45 comments dated From May 2012 to April 2013. A second sample of 125 reviews was taken just after the attack in Sousse.

For Abir hotel, we found only 62 comments, with the last comment being made in August 2014.

Through these samples, we note a few observations :

For the Hasdrubal hotel reviews, $19.32 \%$ of the first sample contained French tourist reviews while French tourist reviews comprised $9.45 \%$ of the second sample. The same trend is observed for the hotel Ksar Djerba, with $16.28 \%$ of the first sample and $8.46 \%$ of the second sample comprising French tourist reviews.

50 The situation is different for the Marmara Dahlia hotel for both samples. Results showed almost stagnation between the percent of French tourist reviews for both samples, with $21.53 \%$ and $18.3 \%$ respectively.

51 We deduct from these remarks that the number of tourists, especially French, declined after the attacks on Sousse. Nevertheless, the Club Marmara stagnation of French tourist reviews is explained mainly by the fact that the Marmara club is a French hotel chain and works exclusively for French customers. 


\section{Disoriented actors who try to resist} managers, mystery shoppers etc. They criticize everything and what they write becomes public. These are not secret notes or letters of warning. Sometimes, customers employ lies, defamation, and insults. One drawback of customer reviews is a failure to respect and protect tourism workers' personal data (fig. 10). Some travellers mention the names of people in unverifiable stories. "The personnel is good, except the head of the bar, $\mathrm{M}^{* * * *}$, he throws my consumption to the figure, because I refused his advances, what stupid... pity that fool $\mathrm{M}^{* * * *}$ has ruined my stay". Dominique G. T. France, stayed June 2014.

Figure 10. In this review, we mention the no respect of personal data for workers

Some hoteliers consistently answer customer reviews. In some hotels, employee's job roles include responding to customer reviews on the internet. In particular, this is often done on TripAdvisor. At times, the hotel's secretary or director replies to customer reviews (Hotel Cedriana Djerba). To avoid unsatisfied clients and bad reviews, some hotels do not hesitate to request that clients' complete quality questionnaires before departing.

\section{Criticizing reviews and tripadvisor}

TripAdvisor refuses signing the AFNOR standard to regulate consumer reviews, arguing that these algorithms were more powerful. In customer-review analysis, mixing the views of well-seasoned travellers with that of inexperienced travellers may be challenging. The reaction to the different culture may be different, and the influence of prejudices may also play a role in their perception.

Hence, an inexperienced traveller may be problematic in giving wise advice or balanced reviews (national customers).

Tripadvisor has also many faults, especially when some hotels want to retract and leave the website. This giant rejects the right to anonymity. The site provides an option to delete a page only after the final closure of a hotel or a change in ownership. To thwart this situation, some companies online offer e-reputation solutions and leave positive reviews on TripAdvisor (fig. 11).

Figure 11. Example of solution to make a good review on Tripadvisor

From internet http://real-tripadvisor-reviews.com

\section{Conclusion}

57 Tourism is a sensitive sector; it depends on several components, including international and national events like terrorist attacks. In Tunisia tourism has suffered since January 2011, due to the events of its revolution and the Arab Spring; the terrorist attacks in Tunis and Sousse in 2015 also caused concern among visitors. The situation in Libya and the threat of Daech caused enormous damage to this country (which was seeking to succeed in a democratic transition).

Communication, technologies et développement, 3 | 2016 
The island of Djerba, in the south-east of Tunisia, is a flagship tourism destination in the Mediterranean basin. Analysis of various customer comments on Tripadvisor helps us discover an island different than what we have known through geography textbooks, tourist guides and postcards. Critics who post on Tripadvisor have always escaped the controls imposed by the authoritarian Ben Ali regime, who did everything they could to convey a beautiful picture of the island. After the fall of the regime in 2011 and the end of this control, Tripadvisor has relayed descriptions of what is happening on the ground. We discover what tourists think of their stays from their arrivals at the airport until their departures. Some reviews seem sincere while others reveal a malicious subjectivity. Eventually, customer reviews on Tripadvisor are very interesting to travellers and hotel administrators. Compared to travel guides, this information is sometimes updated daily, more frequently, then in ; it takes into account new openings, damage in the ancient structures (quality, etc.) and necessary information for travellers. Customer feedback on Tripadvisor gives readers updated information on what is actually happening on the ground in terms of safety and comfort for travellers. The reviews seem to date and allow us to quickly analyse the trend of the sector in a region that has seen some problems. This seems interesting for studies on geographic areas that have experienced recent transformations. Nevertheless, the reputation, acquired through customer reviews on Tripadvisor, hides another facet, related to mercantile targets. This « dictatorship » of customer reviews is increasingly challenged by the actors in the local and national tourism. Annoyed and disoriented, tourism stakeholders do not find any interlocutor, neither at Tripadvisor, nor at the level of officials from the sector. This seems to affect a lot more developing countries, which heavily rely on the tourism sector, than the developed countries. Developing countries do not own the means to cope with these new « intruders » to the sector. A national policy, whether in Tunisia or in other tourist countries, should take into account the emergence of these new digital actors, geographically distant but locally influential, and should provide adequate responses to disoriented tourism stakeholders. Interested countries could also play a part to negotiate with these new actors, through international institutions, such as the World Tourism Organization (UNWTO).

\section{BIBLIOGRAPHY}

Beaude Boris, Internet changer l'espace, changer la société, Fyp éditions, 2012.

Boyer Marc et Viallon Philippe, La communication touristique, coll. “Que sais-je ?”, PUF, 1994.

Despois Jean, La Tunisie, ses régions, Armand Colin, 1961.

Kassah Abdelfettah, «Expansion touristique et réorganisation territoriale dans l'île de Jerba », in $3^{\mathrm{e}}$ colloque du Départementdegéographie de la faculté des Sciences Humaines et Sociales, Tunis (9-11 mars 2000), Tunis, Publication de l'école normale supérieure, 2002, pp. 269-289. 
Mzabi Hassouna, «L'emploi et les investissements touristiques à Djerba », Revue tunisienne de géographie $n^{\circ} 2,1976$, pp. 111-134.

Mzabi Hassouna, La Croissance urbaine accélérée à Jerba et ses conséquences sur la vie de relations avec l'extérieur, Tunis, Publications de l'université de Tunis,1978.

Mzabi Hassouna, La Tunisie du Sud-Est, géographie d'une région fragile, marginale et dépendante, Tunis, Publications de l'université de Tunis,1993.

Neifar Bassem, «Jerba : les mutations récentes d'un système insulaire », Revue M@ppemonde, 77, 2005.

Neifar Bassem, Vers une nouvelle Géographie du Golfe de Gabès en Tunisie : étude géographique d'un espace méditerranéen, Éditions Universitaires européennes, 2011.

Office National Du Tourisme, Le Tourisme tunisien en chiffres, 2001.

Office National Du Tourisme, Les statistiques du tourisme tunisien, in Bulletin mensuel (en arabe), 2002.

Saskia Cousin, Gaël Chareyron, Jérôme Da-Rugna et Sébastien Jacquot, «Étudier TripAdvisor. Ou comment Trip-patouiller les cartes de nos vacances. », EspacesTemps.net, Dans l'air, 29.08.2014

http://www.espacestemps.net/articles/etudier-tripadvisor/

Vásquez Camilla, « Complaints online : The case of TripAdvisor », Journal of Pragmatics n 43, 2011, $13 \mathrm{p}$.

Viallon Philippe, «La communication touristique, une triple invention », Mondes du Tourisme

[En ligne], 7 | 2013, mis en ligne le 30 septembre 2015, URL : http://tourisme.revues.org/171

Sources

I.N.S., General Census of Population and Housing, 1994. I.N.S., General Census of Population and Housing, 2004. I.N.S., General Census of Population and Housing, 2014.

\section{NOTES}

1. Statistics after the 2011 revolution and before the terrorist attacks of 2015.

2. Regional commission of tourism, statistics of 2014.

3. https://www.tripadvisor.fr/PressCenter-c6- About_Us.html.

4. h t t ps://w w w.t r i p ad v i s o r.co m/ TripAdvisorInsights/TripBarometer-en$\mathrm{US} \# \mathrm{tab}=0$.

5. Tripadvisor 2016.

\section{ABSTRACTS}

Before traveling, people more and more consult the Internet, looking for details on places to visit, hotels, national currencies, transport systems, health concerns, and what to do, - or avoid. Discussion forums and personal blogs are a mine of information in which tourists of all 
backgrounds find what they need. In recent years, the "Tripadvisor » portal has become a reference for travellers seeking to know everything about the countries they visit. Launched in 2000, "Tripadvisor» has become a benchmark for travel information. This American website, based on comments and travellers' experiences, may displease professionals in the sector and trouble tourism authorities. "If hoteliers are less subjected to the stress of traditional travel books, they are by contrast to the new guides (Tripadvisor) distributors online (Booking, Expedia...) and rules of SEO on the web." (Viallon P, 2013, p. 8). Protected by nicknames, tourists comment on their experiences. Comments made by tourists in Djerba provide a new reading of the various places, societies and actors involved in Djerba tourism industry. With the increasing importance of the Internet and smart systems to society, geographers discover new depth in spaces they thought they knew well. In this paper, we aim to understand the dynamics of Djerba touristic spaces through the comments of tourists on the Internet. We seek to explore how this tool provides a new understanding of this geographic space and the limits of these tools for geographic researches.

Avant de partir en voyage, les gens utilisent internet pour collecter des informations sur les endroits à visiter, les hôtels recommandés, la monnaie nationale, le système de transport, de santé, ainsi que ce qui est conseillé de faire ou d'éviter. Les forums de discussion et les blogs personnels se sont multipliés et représentent aujourd'hui une mine de renseignements intarissable, dans lesquels les touristes et les voyageurs retrouvent les informations nécessaires à leurs voyages. Lancé en 2000 , le portail «Tripadvisor » est devenu une référence, en matière d'information touristique, notamment, relative à toutes les destinations de voyage. Ce site américain qui bénéficie d'une notoriété sans faille, repose, essentiellement, sur les commentaires publiés par les voyageurs. Les professionnels du secteur et les autorités sont plus que jamais sous pression face à ce monstre géant "Tripadvisor». "Si les hôteliers sont moins soumis à la contrainte des guides papier traditionnels, ils le sont en revanche aux nouveaux guides (Tripadvisor), aux distributeurs en ligne (Booking, Expedia...) et aux règles du référencement sur le web.» (Viallon P., 2013, p.8). En effet, derrière des pseudonymes, de nombreux touristes postent des commentaires, pour décrire avec précision leurs propres expériences, avec plus au moins de subjectivité. Tripadvisor continue à relater directement les expériences vécues sur place. Les observations des voyageurs sur le tourisme à Djerba, révèlent une nouvelle lecture des espaces, de la société et du rôle joué par différents acteurs œuvrant à y promouvoir le tourisme. Le développement de l'utilisation d'internet et des nouvelles technologies de l'information et de la communication, a permis au géographe de redécouvrir d'autres facettes d'un espace qu'il pensait parfaitement connaître à travers les manuels classiques de géographie.

À travers les commentaires laissés par les touristes sur Internet, cet article vise à comprendre les nouvelles dynamiques touristiques à Djerba, le rôle de ces outils dans la connaissance des espaces géographiques, et à évaluer les limites de ces nouveaux outils de recherches.

Antes de viajar, más y más personas consultan internet, enbusca de detalles sobre los lugares a visitar, los hoteles, las monedas nacionales, sistemas de transporte, problemas de salud, y qué hacer o evitar. Los foros de discusión y blogs personales son una mina de información en el que los turistas de todos los orígenes encontrar lo que necesitan. En los últimos años, el portal «Tripadvisor » se ha convertido en una referencia para los viajeros que buscan saber todo acerca de los países que visitan. Lanzado en 2000,

"Tripadvisor » se ha convertido en un punto de referencia para la información sobre el viaje. Este sitio web estadounidense, basado en los comentarios y experiencias de viaje, puede desagradar a los profesionales de las autoridades del sector y turismo problemas. "Si los hoteleros están menos sometidos a la tensión de libros de viajes tradicionales, no son en contraste con las nuevas guías (Tripadvisor) distribuidores en línea (Reserva, jun...) y las normas de la SEO en la web. » (Viallon P, 2013, p. 8). 
Protegido por apodos, los turistas comentan sobre sus experiencias. Los comentarios realizados por los turistas en Djerba ofrecen una nueva lectura de los lugares diferentes, las sociedades y los actores involucrados en la industria del turismo de Yerba. Con la creciente importancia de internet y los sistemas inteligentes para la sociedad, geógrafos descubrir una nueva profundidad en los espacios que pensaban que conocían bien.

En este trabajo, nuestro objetivo es entender la dinámica de los espacios turísticos Yerba través de los comentarios de los turistas a través de internet. Buscamos para explorar cómo esta herramienta proporciona una nueva comprensión de este espacio geográfico y los límites de estas herramientas para investigaciones geográficas.

\section{INDEX}

Mots-clés: djerba, tourisme, commentaires clients, tripadvisor

Palabras claves: yerba, turismo, críticas, web 2.0, crowdsourcing, tripadvisor

Keywords: djerba, tourism, reviews, web2.0, crowdsourcing, tripadvisor

\section{AUTHOR}

\section{BASSEM NEIFAR}

UMR Telemme, Aix-Marseille University and CNRS France 